\title{
Article \\ The New Responsible Tourism Paradigm: The UNWTO's Discourse Following the Spread of COVID-19
}

\author{
Sabrina Tremblay-Huet ${ }^{1}$ and Dominic Lapointe ${ }^{2, *(D)}$ \\ 1 Faculty of Law, Université de Sherbrooke, Sherbrooke, QC J1K 2R1, Canada; \\ sabrina.tremblay-huet@usherbrooke.ca \\ 2 Department of Urban and Tourism Studies, University of Quebec in Montreal, Montreal, QC H3T 1J4, Canada \\ * Correspondence: lapointe.dominic@uqam.ca
}

Citation: Tremblay-Huet, S.;

Lapointe, D. The New Responsible Tourism Paradigm: The UNWTO's Discourse Following the Spread of COVID-19. Tour. Hosp. 2021, 2 , 248-260. https://doi.org/10.3390/ tourhosp2020015

Academic Editor: Brian Garrod

Received: 18 May 2021

Accepted: 3 June 2021

Published: 8 June 2021

Publisher's Note: MDPI stays neutral with regard to jurisdictional claims in published maps and institutional affiliations.

Copyright: (c) 2021 by the authors. Licensee MDPI, Basel, Switzerland. This article is an open access article distributed under the terms and conditions of the Creative Commons Attribution (CC BY) license (https:/ / creativecommons.org/licenses/by/ $4.0 /)$.

\begin{abstract}
The UNWTO's discourse has focused on managing the effects of COVID-19 on tourism mobility since the outbreak was taken over by the WHO, as tourism is prominent amongst the hardest hit sectors. Emanating from the UNWTO as one of the dominant stakeholders in tourism discourse construction, an interesting component is the new meaning attributed to 'responsible tourism', which coincides with severe sanitary measures in this moment. Through critical discourse analysis and the theoretical framework offered by Iris Marion Young on responsibility for justice, this article will first demonstrate how the reappropriation of the term is in line with the UNWTO's neoliberal perspective on tourism. The result is the promotion of sanitary measures for the protection of tourism as a consumer industry, rather than for the protection of the individuals involved. It is also cementing the pedestal on which the UN agency places the tourist-consumer, namely through the International Code for the Protection of Tourists project. This paper closes with thoughts on how the emerging dominant discourse on responsible tourism is internalized by tourism stakeholders as the new normal, which would gain in being explored through the lens of Foucault's work on the concept of biopolitics and the neoliberal subject.
\end{abstract}

Keywords: responsibility; UNWTO; biopolitics; social justice; COVID-19

It has become a truism to state that tourism is hard-hit by the COVID-19 pandemic. As we are writing those lines in June 2021,56\% of destinations have entry restrictions while measures such as quarantine, mandatory testing and a vaccine passport are present in more than half of the destinations of the world. The volume of international travel is still estimated as being $87 \%$ lower than the year to date compared to 2019 [1]. While the vaccination campaigns are unfolding in many countries, on 29 May 2021, only Israel has more than $50 \%$ of its population considered fully vaccinated (56\%), stressing an unequal access to vaccines among the rich and poor countries. While the vaccine passport is discussed as key to recovery of international travel [2], its many ethical issues are still up for debate, especially for its capacity of creating categories of citizens [3] with very different mobility access [4].

In this context, tourism recovery is, of course, a centerpiece of the United Nations World Tourism Organization (UNWTO)'s discourse. What is of particular interest for this paper is the reappropriation, in this dominant institutional discourse, of the concept of 'responsible tourism' to include sanitary considerations. Whereas prior to the COVID-19 pandemic, the question of who could claim this right to be a transnational tourist was shaped by factors such as socioeconomic status and nationality, the post-COVID-19 era adds a sanitary factor as central to this question. While responsible tourism has been mostly associated with sustainability [5], the pandemic is bringing responsibility into the sanitary discursive field. As the concept of 'responsible tourism' is reappropriated to include sanitary considerations, we must ask: who does this benefit, who is restricted by such considerations, and what other aspects of 'responsible tourism' does this marginalize? We argue that the elites, both those who benefit economically from tourism and those who 
benefit from tourism in leisure terms, remain the main actors shaping tourism recovery to match their interests. Strict sanitary measures aim at safeguarding tourism as an industry, notwithstanding the professed concerns expressed by the UNWTO for tourism workers. Mobilizing Iris Marion Young's work in Responsibility for Justice [6], our paper seeks to demonstrate how this internalization of the new biosanitary norms of what constitutes responsible tourism is problematic from a critical tourism studies perspective. This will be done through a critical discourse analysis [7] (CDA) of the use of the term 'responsibility' in the UNWTO's communications.

\section{COVID-19, the Major Tourism Pause, and Sanitary Measures as a Path to Recovery}

The UNWTO World Tourism Barometer is an instrument reporting the latest statistics on the state of tourism, which demonstrates the drastic fall in all elements measured since the novel coronavirus was declared a pandemic by the World Health Organization (WHO). The UNWTO Global Tourism Dashboard is an additional tool dedicated more specifically to the impact of COVID-19 on tourism. It reports that from January to August 2020 , international tourist arrivals have decreased by $70 \%$ as opposed to the same period in 2019, estimating that the losses incurred are eight times higher than those caused by the 2008 global economic crisis for the year 2009. The year 2023 is the projected best-case scenario for international tourist arrivals to reach the same numbers as prior to the COVID19 pandemic. Furthermore, the UNTWO has been monitoring travel restrictions since April 2020. As of 1 September, 113 countries still had travel restrictions in place out of the 115 monitored by the UNWTO, of which 93 prohibit incoming transnational tourism completely at the moment. The tourism pause caused by COVID-19 is longer for countries with what are considered by the UNWTO as 'relatively low scores in health and hygiene indicators,' creating a vicious cycle in terms of recovery as many such destinations are economically tourism-dependent.

In November, Australian airline Qantas was the first to announce that a COVID-19 proof of vaccination would be mandatory to get on one of their flights. The company expected at the time that this will be the new standard, and indeed got the ball rolling on this sanitary tourism direction. Echoing such a direction, the UNWTO mentioned that the novel Global Tourism Crisis Committee is working on the idea of a health passport (https: / / www.unwto.org/news/madrid-set-to-host-key-week-for-global-tourism, accessed on 4 June 2021). The Committee also promotes coordination with the WHO, viewing 'common, harmonized digital related travel principles, protocols and documents' as essential. Albeit a discussion for another context than this paper, we must note the dangers of normative harmonization as relates to power relations between the Third World and the West. Europe may become the theatre of a first type of health passport related to COVID-19, in the form of a Digital Green Certificate (COM/2021/130), for vaccination, testing and recovery.

The World Committee on Tourism Ethics met in June 2020 and issued a statement recalling the importance of 'ethical principles' in applying public health measures to tourism recovery. Drawing from the Global Code of Ethics for Tourism and the Framework Convention on Tourism Ethics, the Committee enumerates the following principles: nondiscrimination and equity; accessibility; tourist and consumer protection; protection of data privacy; protection of the right to an informed decision; and workers' rights and social protection. It should be noted that these are not presented in alphabetical order, which does not explain why 'workers' rights and social protection' is stated last. In any case, such principles might nonetheless be at odds with current and future sanitary measures imposed by states and private actors. Indeed, access to vaccines (any vaccine, not only the novel COVID-19 vaccine) is notoriously unequal amongst nations. In March 2021, the UNWTO called upon nations to share vaccines with Small Island Developing States, in order to speed the recovery of tourism in these states. Another notable development in this arena is Cuba's development of several vaccines against COVID-19, leading to a potential new avenue for medical tourism in the form of 'vaccination vacations'. 
Sanitary measures are thus expected to continue dominating tourism policies worldwide in the foreseeable near future. How these are, and will be, linked to the concept of 'responsible tourism' is of main interest to this article.

\section{Methodology: Critical Discourse Analysis}

To answer this question, our paper mobilizes the methodology of CDA, guided by a theoretical framework inspired by Young. Responsibility is not a new concept in the discussion of ethics and justice. Philosophers such as Hans Jonas [8] with the responsibility principle, or Emmanuel Levinas [9], with intersubjective responsibility, have conceptualized responsibility as core to their work and their vision of ethics. For our purposes, we will mostly turn to the work of Iris Marion Young [6] and her posthumous book Responsibility for Justice to expose what is responsibility for justice and how responsible tourism stands with it. This theoretical anchor allows us to add characterizations to the power relations at play in the tourism sector's response to the COVID-19 pandemic's catastrophic impact.

Discourses are important moments of the social process, as they have the capacity to frame understandings of nondiscursive practices [10]. Tourism holds a strong discursive dimension. As Dann [11] exposes, tourism is a language of power, contributing in defining what can be done where and by whom. Therefore, tourism acts as a 'world-making process' $[12,13]$, which is especially accurate in the case of self-enclosed enclave tourism [14,15], but also for more interwoven tourism practices in place [12,16-18]. On a larger scale, different stakeholders shape the discursive field of tourism, who in return shape the possible practices, which is especially true of international organizations within the hegemonic neoliberal project [19-21]. In this context, the UNWTO is one of the major discourse shapers in the global tourism system, its statements being relayed through various paths by NGOs, academia, nation states and local administrations in their decisions, actions and policies.

It is the transformations of the tourism discursive field by the COVID-19 pandemic that we will grasp through a CDA of the UNWTO discourse. The critical stance is necessary to question and challenge dominant tourism discourses about capitalism, development and justice, especially in the context of largely coopted sustainability discourse and practices [22,23]. CDA is about exposing the relationship between the discourses and its subjects, and the power of those discourses in shaping the subject as well as shaping subjectivities facing this subject [24]. In the realm of policy making and policy shaping, in which the UNWTO acts, the importance of those discourses is central, because discourses are exposing power relationships.

"The power to control discourses is seen as the power to sustain particular discursive practices, with particular ideological investment in dominance over other alternatives" [7].

The importance of discursive analysis to assess power relationships makes it quite relevant to assess the transformations incurred by the COVID-19 pandemic to the discourse of a hegemonic discourse producer such as the UNWTO. CDA works on three dimensions: the text itself (what it says), the order of discourse (how it relates to the other discourses shaping its particular domain, including the boundaries of the domains) and, finally, the social interactions it creates with the subjects of the domain [7]. Attention to unequal power relations characterizes the 'critical' dimension of CDA [25]. In this sense, we mobilize CDA in order to render explicit the hierarchies implicitly present in the UNWTO's discourse on responsibility in the context of the COVID-19 pandemic. We seek to render visible the subjective nature of the language mobilized by the UNWTO, which favors the dominant tourism stakeholders through a consumer-centric, market-oriented meaning attached to responsibility. As summarized by Wodak and Meyer [25], 'CDA aims to investigate critically social inequality as it is expressed, signalled, constituted, legitimized and so on by language use'.

In order to proceed to the CDA, we gathered the UNWTO's press releases, sent to the organization's mailing list, from 20 January 2020 onward. This corresponds to the date of the first UNWTO press release about the novel coronavirus, later referred to as COVID-19. 
This paper considers as the corpus for its CDA the press releases published until 14 May 2021. This qualitative data sample amounts to 148 pages (See Appendix A).

Within this corpus, the keyword 'responsible' is what garnered our attention the most, in terms of how it was mobilized. What was the context? Did it explicitly or implicitly refer to sanitary considerations? How did this specific reference fit into the broader UNWTO narrative surrounding the COVID-19 pandemic? Other references to key concepts, such as growth, consumer-centric ideas, and health and rights of tourism workers, were also of significant interest for our analytical purposes. On the other side, we did not address the sustainability discourses that were associated with responsible tourism prior to the pandemic, nor the discursive field of sustainability, nor tourism and justice as carried by the transnational institutions already having been identified as now constitutive of the neoliberal market institutions $[19,20,26]$.

Our CDA focuses on: Whose responsibility is stressed by the UNWTO in the COVID19 related discourses? Through which measures responsibility is called upon? How does this discursive and historical moment of the UNWTO shape tourism in its actual and future forms?

\section{Analytical Framework: Responsibility for Justice}

We discuss the result of the CDA through Young's [6] social connection models of responsibility for justice. Young [6] exposes critically the issue of the dissociation of individual responsibility from structural injustice in the welfare policies and discourses where the former become the main explanation for poverty, failure, crime and so forth Young's argument is that you cannot dissociate the two spheres of responsibility, the personal and the structural, which she called the political. If individuals have responsibility in their situation, it is within a political and institutional context and therefore there is a political responsibility in scrutiny of those institutions that frame the context. No individual being is isolated from the social and political structures. She articulates her model around four interrelated parameters of responsibility: power, privilege, interest and collective ability.

Power relates to the capacity agents have over an issue of justice. Indeed, in a tourism system, different agents have different levels of power over issues such as labor conditions, environmental degradations, climate change mitigation and sanitary security. By agents, we mean as much individual agents such as a tourist, worker, resident, entrepreneur, and politician, as organizations such as governments, NGOs, municipalities, businesses or international institutions. The power can be formal, such as embedded in laws and regulations, or informal in the power over issues through influence and actions.

Privileges are closely related to power, where they even often coincide with power, but not all the time [6]. To illustrate the latter situation, Young [6] gives the example of Western middle-class consumers' privilege of benefitting from a large choice of apparel to buy at reasonable prices, but at the expense of the injustice generated by sweatshop workers' conditions, whereas Western lower-class consumers have less privilege to change their habits to act on sweatshop workers' conditions. Responsible tourism tends to focus on the ability of the affluent's privilege to make different choices in the accomplishment of their leisure privilege mobility [27] and the power of organizations and destinations to offer such choices.

Interest is closer to the motivations of the different agents to accept the injustice because it serves their interests. The range of what Young [6] includes in looking at interest goes from the interest to have a wage, even if it is deemed an unfair wage, to the interest of keeping high profit activities to fuel shareholders' dividends, with all the different levels of interest in between.

Finally, collective ability refers to the political capacities of agents of bringing the issues of injustice into the political arena. "When I name 'collective ability' as a parameter that agents might use to think about what to do about a structural injustice, I have the following 
in mind. Some agents are in positions where they can draw on resources of already organized entities and use them in new ways for trying to promote change" ([6], p. 147).

Indeed, Young [6] stresses that shared responsibility is a political responsibility. In the political field, some powerful agents have the collective abilities to maintain injustice and imbalances of power that serve their interest and sustain their privileges. The collective ability of responsibility for justice is central to Young's perspective on justice, because this political responsibility underlines that of facing structural injustice. Individual actions are not sufficient-institutions are needed to create a political field for acting on the injustice. This field is built on shared social and economic interactions, calling for the emergence of shared political institutions that can create power relationships with structural injustice [28]. This relational turn Young [6] gives to responsibility also exposes the fact that few institutions address global injustices.

\section{Responsibility and Responsible Tourism to Answer to COVID-19}

Responsible tourism is defined as a form of tourism that assumes responsibility of its economical, social and environmental impacts, with the ultimate goal of achieving sustainability [5]. Borrowing the three pillars of sustainability, it acknowledges the diversity of the world and of the stakeholders involved in tourism as it is declared in the 2002 Cape Town Declaration, and holds the possibility of reflexivity and transformation.

"Following Iris Marion Young, if tourists contribute to structural or global injustices, even simply by being part of a network or structure that connects them to sources of injustice, then they are responsible to do something about it. It requires understanding the social systems and processes related to the observed injustice and where they fit into it, and engaging in political responsibility to change these to reduce or eliminate unjust outcomes" ([29], p. 111).

Although there are initiatives addressing this structural and political dimension of responsibility, Young's critic of responsibility in welfare discourses and policies can be voiced about tourism. As Grimwood et al. [30]) underline it, while not wanting to disqualify the potential of responsible tourism, tourists, and we would add tourism organizations, stay mostly embedded in the different dominant discourses, one of them being neoliberalism $[19,22,31]$.

Neoliberalism goes beyond the mere credo of the market as the main economic institution and the rejection of State intervention, or should we say the rejections of some forms of State intervention: it is a cultural and political revolution [32,33]. Revisiting Foucault's Birth of Biopolitics [34], Brown [33] stresses the importance of the emergence of Homo Oeconomicus as the central subject of the neoliberal project:

"Focus on this character is what permits Foucault to feature neoliberalism as a novel contemporary chapter in liberal governmentality, one that foregrounds the problem of governing homo oeconomicus (and the economy as a whole) 'without touching it'." (Brown 2015, p. 57).

This implies that market principles become the guiding principles of every sphere and activity, including life and emotions, social needs and even death. This centrality of homo oeconomicus and the market as the structuring principle of politics and social life also creates a depoliticization of social life, where subjectivities are created through the market and competitions between market stakeholders through a biopolitical production of society [35]. By biopolitics, we refer to power over the production and reproduction of life itself [34] and subjectivity formation [36], where the political stake corresponds to power over society (seen as a group of people), the power to organize life, its conditions, rules and the power to let die [37]. Biopower is aimed at bodies, those of individuals, but also of all people in a given place, in order to protect, strengthen and reproduce in the economic interest and policy of the state and the economical powers that be. The COVID-19 pandemic brought to the fore the relation between biopolitics and neoliberalism, as Jeff Rose [37] frames it, through a tripartite typology of labor forces: essential labor, labor that has been lost and labor that has been moved online. As a result of the neoliberal 
politico-economic context in which this sanitary crisis is evolving, we are witnessing an 'uneven exploitation of labor [that] renders lives associated with some labor functions as more expendable than others'. The biopolitical dimension of neoliberalism is exemplified by the internalization of market rules by individual and private economic wellbeing as the paramount of social success. This brings us back to the issue of responsible consumption, and responsible tourism.

Responsible consumption is about the capacity of the individual as a form of neoliberal subject, the consumer, to make choices that are better for oneself and for society. Through numerous choices, the informed responsible consumer makes 'rational' choices that express its responsibility to lessen impacts. On the other side, you have the private organizations (and NGOs, to a lesser degree), through corporate social responsibility, (CSR), which offer to the demand products and experiences that correspond to this responsibility. While this virtuous circle seems hard to criticize, it shows a depoliticization of responsibility towards a negotiation of responsibility through the market and the internalization of market dynamics by the individual. Subjectivities are not in the political sphere anymore; they are competing in the market [19]. This situation shows the pitfalls of calling for responsibility as an organizing principle, because in this form it lacks the second condition identified by Young to achieve responsibility for justice, which is the political responsibility facing structural inequalities and injustice. It is from those premises that we will look critically at the UNWTO's discourse on responsibility and tourism in the face of the ongoing COVID-19 pandemic. Discourses of this sort are discourses of power and constitutive of reality $[11,13,24]$.

\section{The Evolution of Responsibility within the UNWTO Discourse}

Our theoretical direction as concerns our understanding of responsibility now presented, we turn to the UNWTO's mobilization of the concept in the context of the COVID-19 pandemic, in relation to tourism. The use of the term 'responsible' by the UNWTO started with its first statement about the virus, on 31 January 2020. Both the sector and the tourist are presented as having responsibilities to maintain during this outbreak: 'During times of crisis, tourism has to live up to its responsibility as an integral part of wider society. [ ... ] Tourists also have a responsibility to inform themselves before they travel in order to limit the threat of transmission, and they should follow the recommendations of the $\mathrm{WHO}$ and their own national health authorities'. In its 28 February 2020 statement, the message is that the 'UNWTO will continue to work closely with its partners, including the World Health Organization (WHO), to ensure the tourism sector responds to an evolving situation in a measured and responsible manner'. This refers to the recommendation from the UN agencies that there not be 'unnecessary interference with international traffic and trade'. Of course, what constitutes an unnecessary measure lies within the eye of the beholder.

The more explicit turn towards 'responsible' as a sanitary reference came on 17 March. A statement from Secretary-General Pololikashvili refers to 'a duty of care to themselves and others' for people still traveling, adding that ' $[t]$ here can be no excuses and no exceptions as people around the world are living up to their responsibilities'. Mr. Pololikashvili presents tourism recovery using the responsibility lexicon again on 15 May 2020, emphasizing that the UNTWO has 'been encouraged by the action plan set out by the European Union to relaunch tourism in a timely, responsible and coordinated manner'. The statement refers to 'new health and safety protocols for every part of the tourism value chain', and not to any environmental or social measures, although that will come later in the international organization's discourse. Another example is the 1 July 2020 statement by SecretaryGeneral Pololikashvili to the effect that 'even where the worst appears to have passed, the threat of the pandemic returning means we must act responsibly and make public health our priority'. Such calls are considered as having been heard as soon as August, when Mr. Pololikashvili affirms that ' $[\mathrm{b}] \mathrm{y}$ and large, people have learned how to behave in a responsible way. Businesses and services have put protocols in place and adapted their 
operations'. The organization thus observes a behavioral change towards strict conformity with sanitary rules.

As the pandemic evolves, we witness a shift in the discourse from 'responsible' and 'safe and responsible' towards 'safe travel', albeit in an inconsistent manner. The discourse of responsibility now again at times refers to environmental and social elements, such as in November, when the UNTWO announced that ' $[t]$ he Global Tourism Plastics Initiative can lead to the reduction of pollution and waste across all parts of the tourism sector and support a responsible recovery from COVID-19 that leads to more sustainability and resilience', or when it announced a guide for a more inclusive tourism sector as concerns persons living with disabilities. The inconsistency as relates to what 'responsible' refers to is namely put forward by the subsequent use of statements such as this: 'safe travel is possible and so tourism can restart responsibly'.

The mainstays of the UNWTO discourse have been the centrality of the consumer and neoliberalism, which the COVID-19 pandemic era maintains. The consumer-centric approach to the tourist adopted by the UNWTO was consolidated especially by the 'right to tourism' enshrined in both the soft law Global Code of Ethics for Tourism (1999) and the binding Framework Convention on Tourism Ethics (2017). Indeed, framing an individual's act of leisure tourism as a right through legalization, being the explicit interpretation of the International Covenant on Economic, Social and Cultural Rights (ICESC)'s human right to rest and leisure, represents one of the ultimate forms of social legitimization and the culmination of the UNWTO's normative discourse on this idea [38,39].

This orientation has not wavered in light of the pandemic and its deleterious impacts on host communities in tourism-dependent locations. The 16 June press release from the UNWTO claims that '[r]estarting our sector must be done in a timely and responsible manner, avoiding at all costs coming at the expense of fair and equal treatment of tourists' (our emphasis). Additionally, the pandemic inspired the UNWTO to reinforce the consumercentered, 'right to tourism' approach by announcing an upcoming International Code for the Protection of Tourists (Such a new legal instrument warrants a separate analysis, outside of the purview of this article, aimed at deconstructing the new meaning of 'responsible tourism' in the context of the dominant tourism discourse). Furthermore, the September 2020 Tbilisi Declaration, Actions for a Sustainable Recovery of Tourism, states in its preamble that ' $[\mathrm{t}]$ he appropriate mechanisms should be established so that tourists receive the fullest attention at the destination, thus converting trips into a space and a time of happiness'.

Similarly, the unlimited growth mindset characterizing the neoliberalist approach to tourism promoted by the UNWTO has not been halted by the pandemic in terms of objectives, but rather only in temporal terms. Growth has retained its status as a virtue. Even as international tourist arrivals were reaching higher statistics every year, the UNWTO promotes a return to economic growth as early as 17 March. This was echoed by the UN Secretary-General Antonio Guterres, who in June deemed tourism 'a pillar of economic growth'.

In the neoliberal era, everything is economicized, including people [33]. The language adopted by the UNWTO speaks volumes to this orientation. In the aforementioned 2020 Tbilisi Declaration, it is stated, under the section 'For the people': 'Promoting education and skills development to increase the agility and value of human capital' (our emphasis). When the UNWTO recently presented its inclusive recovery guide on the topic of persons living with disabilities, it argued for the perspective of 'accessibility as a competitive advantage'. It supported this namely by giving the example that tourists living with disabilities spend on average 200 Euros more during a vacation in Spain as opposed to tourists who do not live with a disability (ibid). A further example of this can be gleaned from a December 2020 press release that states: 'Even as the news of a vaccine boosts traveller confidence, there is still a long road to recovery. We thus need to step up our efforts to safely open borders while supporting tourism jobs and businesses'. Tourism workers are reduced to their jobs rather than their health holding an intrinsic value, as that is how they are characterized, in a generous interpretation of this statement. A more cynical interpretation 
would be for 'jobs' to refer to a purely economic determinant. Similarly, a press release closing 2020 with what is termed 'determination', announces that 'The UNWTO Global Tourism Crisis Committee [ ... ] coordinates international efforts and has proven to be crucial in guiding our response to COVID-19 and informing the measures and tools for mitigating its impact on jobs and businesses'. Host communities are reduced to jobs and businesses. The measurement of success, as concerns tourism recovery from the pandemic, is circumscribed to these economic indicators. Ignored from this discourse are the health, safety and freedom from constraining sanitary measures of such communities, let alone contributing to improving environmental justice.

The four poles of analysis from Young apply to the redefinition of 'responsible tourism' in the context of the UNWTO's response to the COVID-19 pandemic. First, power: what is striking in this dominant discourse is how powerless the consumer is presented. Tourists are considered as highly vulnerable [38]; yet, the UNWTO insists on restoring tourist confidence in travelling, recognizing the power they hold in revitalizing the sector. The early call of the UNWTO to refrain unnecessary interference in international travel could be seen as an erosion of the UNWTO's power, as major restrictions were in place a month later. This shows a struggle for the power of defining what is necessary travel and unnecessary interference to travel. This will lead to a merging of discourses on responsibility between sanitary responsibilities and economic responsibilities, the sanitary discourse being the one at the forefront with a new, and since then renewed, power over society and mobility. It is through an argument centered on the economic power of tourism that the UNWTO's call for a responsibility towards a fast recovery of tourism is paired with sanitary rules to protect the tourist. This unfolded while the knowledge about the virus' behavior and possible mutations were still not fully understood.

Second, privilege: to even think about being a responsible tourist breathes privilege, let alone simply being a leisure tourist. In this new social reality created by COVID-19, a biopolitical component has been added to the privilege of being part of the leisure class [39]. Privilege, however, as Young reminds us, is relative (2013, p. 145); to be a responsible tourist is not an option for all.

Third, interest: Young posits that 'victims of injustice should take some responsibility for challenging the structures that produce it' (2013, p. 145). A window of opportunity is certainly opened at this point in the process of restarting tourism. Hopefully, 'there may be agents in addition to victims whose perceived self-interest may coincide with promoting justice' $(2013$, p. 146). While some authors called for a tourism recovery on different bases than before the pandemic $[40,41]$, the economic interest of the giants of the sector and the main Western destinations are forefront on the path to recovery. This path is punctuated by testing capacity, hospitals capacity and vaccine inequalities in favor of the rich countries of this World, while leaving few opportunities for the unaccounted for to challenge the new tourism emerging. The UNWTO's discourse of responsibility is quite exclusive: while it does voice concerns for tourism-dependent states, it does not critically address the impacts of this dependence and the interests of those countries seeking alternative paths of development.

Fourth, collective ability: this window of opportunity needs to be explored beyond the economic governance to bring back tourism development and planning within the political sphere and within forums such as international organizations such as the UNWTO, but also within national tourism boards and airlines and tour operators. The discourse of responsibility that is emerging from the UNWTO is failing to address injustice in its market-based orientation, leaving no space for political collective abilities. As Guia [22] states, inclusion of values to create justice-aimed forms of tourism have somewhat failed as they are commodified, depoliticized and coopted by the neoliberal capitalist project. Summarizing responsibility as creating the conditions for the return of tourism businesses and collective abilities as an act of consumerism is an emptying of the possibility of responsibility for justice. This situation is emblematic in the overly simplistic and exceedingly positive perspective on tourism promoted by the UNTWO which has not evolved with 
the COVID-19 pandemic in the organization's discourse; it remains that tourism is presented as being a cure-all if one follows directions towards fostering perpetual growth, valuing demand (the consumer) above all else in order to achieve this, demands that are implicitly considered responsible. Furthermore, it is far too easy to feel disconnected from a responsibility towards a host community of tourism located elsewhere than one's own community. Let us recall how Young [6] responds to self-limiting constructed boundaries as it relates to our sense of personal responsibility, in the context of transnationalism: 'An agent's responsibility for justice is not restricted to those close by or to those in the same nation-state as oneself, if one participates in social structural processes that connect one to others far away and outside those jurisdictions'. On the other side, the recurring reliance on the market as a vector of responsibility shows how the transnational political system lacks other institutions to reassemble power, privilege and interest to address injustice. It is especially true for tourism, where the tourist is portrayed as a post-political figure moving from place-to-place without engaging politically [42], creating a political liminal space between home and destination with no clear institutions for collective ability but the market. The interplay between shared responsibility about the safety and economic security of host communities of tourism and the biopolitical measures contemplated (i.e., testing, vaccination) warrants a closer analysis, mobilizing Foucault's contribution.

\section{Closing Remarks: The Biopolitical Dimension of the Discourse of Responsibility}

Following the insistence of the UNWTO on restarting tourism and of forecasting a timeline to its recovery back to its previous level as part of responsibility, without secondguessing the actual desirability of this level of tourism, creates a pressure to open for business tourism destinations that could be seen as mirroring Rose's [37] tripartite division of labor. Indeed, firstly, you have the affluent countries that can keep their borders closed and rely on their population through domestic growth of tourism, most notably China and the United States, or support their tourism industry through state-led recovery programs, such France and Canada. Those echo the labor that can be transposed online. They answer the responsibility call from the UNWTO in part by letting their borders closed and with a monitored mobility, while being ready for vaccinated travelers, as the European Union reopening for vaccinated travelers from the United States. It is of interest to underline that it will mostly be the 'working safe from home' mobile class of the same countries who will be able to access vaccination, insurance, time and money to access newly opened international travel destinations.

Secondly, you have countries where international tourism dollars are deemed essential for their national budget and satellite accounts, which echo the situation of essential workers, especially those in the reproductive functions of society. Such countries will figure out ways to secure and reassure the mobile bodies of tourists and the multinational operators in need of restarting their activities, with rapid testing, contactless business operations in resorts, individual protection artifacts for workers, and the like. We can think of countries such as Mexico, Thailand and Greece. While responding differently to the responsibility call of the UNWTO, those countries, such as essential workers, bear a larger risk in doing so for their population and their healthcare system, but also for the tourists, which are more than likely the middle-class consumers traveling to escape the hardship of daily work.

Thirdly, you have the countries where tourism just vanished; the resources to apply sanitary rules are not available and the population is not demographically or economically sufficient to support the industry through domestic tourism. We can see in this category Latin American countries such as Argentina or Venezuela; and African countries such as Senegal, Tunisia or Mozambique. It is also important to underline that those countries were facing a harsh pre-pandemic situation for their respective tourism industry, due to political or environmental constraints.

What we see in the responsibility of an urge to recover tourism to pre-pandemic levels is a new ordering of the tourism system around the capacities to negotiate the mobile body 
from a threat to an opportunity. While affluent countries can shelter their national space from mobile bodies seen as a threat, they also secured their national bodies and expose them as fit and safe to travel through vaccination on their side and sanitary measures on the host's side. Then, you have countries that cannot afford to shelter their space while trying to create pods, hubs or islands of safety for visitors, despite having difficulties protecting their own populations, just as essential workers in grocery stores and distribution centers working with the risk of a COVID-19 outbreak in the workplace. Finally, you have the left out, those that following the reasoning of the UNWTO could be deemed as irresponsible, not being able to secure and revive their tourism industry.

We can see that calling for the responsibility of a sanitary reopening of tourism will be a multitier effort, and that it will rely on biopolitical decisions aimed at securing the mobile bodies and (re)creating place around the sanitary measures, with the risk of creating closed spaces of total alterity [16] to answer the right to travel and the economic imperative of strong currencies for countries disadvantaged by the neoliberal political economy. We can already see mobility injustices due to sanitary restrictions creating a new axis of redistribution of mobility (which is superimposed on old ones), and, at the same time, states facing a real public health issue [4].

It is this contradiction that the UNWTO tries to minimize by pushing tourism recovery around a virtuous discourse built on truncated responsibility centered on the sanitary and the economy with no political debate whatsoever. This involves responsible tourism that is discursively transformed towards a sanitary core, immunizing the bodies and the destinations to support the economy. This discursive transformation is mostly in favor of affluent countries being able to support their tourism economy. We see in this a concentration of power and privilege, facing divergent interests (economic development through hedonistic travel and sanitary protection) by summarizing the collective ability to the sole economic collectivity - neoliberal subject-therefore organizations, but also the productive privileged who need to get away from their teleworking from home to become productive again afterwards, even if it is through raising the risk for less affluent countries that secure tourism enclaves due to a necessity of capturing the economic benefits. Following Rose [37], we exposed the biopolitical outline of the discursive modification of the responsibility by the UNWTO, echoing the ordering of who works and risks his or her life and who is confined in a relative comfort that will make them even more entitled to travel under the virtue of responsibility, circling this back to Young's [6] four themes of responsibility for justice.

It is unclear how the UNWTO will mobilize the vocabulary of 'responsible tourism' further as vaccination ramps up and borders reopen to tourism, and how it will intersect with terms such as 'safe travel' and 'sustainable tourism/development'. The Tourism Ethics Committee recently called for a 'responsible' use of travel certificates, also stating that such certificates can be 'compatible with ethical tourism'. Furthermore, Ministers of Tourism in the Americas recently adopted, under the aegis of the UNWTO, the Declaration of Punta Cana. In this nonbinding instrument, responsibility is referenced to twice. Namely, the Parties declare: 'That we reaffirm the responsibility and commitment of all governments and international organizations to provide support to tourism in order to ensure its swift, effective, safe and sustainable recovery'. Furthermore, the Parties also declare: 'That we are orienting the restart of tourism towards becoming a responsible and sustainable sector that promotes inclusion, gender equality and accessibility for all'. What is clear is that the UNWTO has not put forward an explicit definition of 'responsible tourism' and what this means specifically in the context of the recovery from COVID-19. Lack of clarity can most certainly leave the door wide open to instrumentalization of the term by elites, and, thus, of the revitalized sector. As with terms such as 'ethical', 'sustainable' or 'ecological', one must be alert to who is defining them, and to what extent the 'market' retains power in filling the gaps of vague understandings of these terms used as labels to sell tourism experiences.

The COVID-19 pandemic was, and still is, a major shock for the tourism practices. It generated a mix of responses, from a call to address tourism issues and flaws to rebuild it 
on a more sustainable and ethical ground $([40,41]$ to a concern to a fast back to business as usual [43]; it is too soon to stipulate what tourism will look like, the historical distance not yet there [44], but we can foresee that with its previous economic importance, tourism will matter in the global post-COVID-19 recovery [45].

As we expose throughout our analysis, the situation was evolving fast and stakeholders were trying to redefine the playing field of tourism and the new rules to set up to get it back on track. We focused on one particular stakeholder, the UNWTO, for its capacities of transforming the discursive field at the global level. We exposed a translation of the meaning of responsibility from an environmental and sustainability discursive field towards a sanitary risk mitigation discursive field. This translation is combined with previous tourism issues framed through a set of discourses, such as growth management and geopolitics, while adding to them a biopolitical dimension [46]. While there is still hope for a more just and sustainable recovery of tourism post-COVID-19, it is obvious from the analysis of the emerging discursive field of sanitary responsible tourism that it is woven with neoliberal growth discourses, and therefore we should not underevaluate the capacity of the market to feed on risk as a growth factor [47], and especially on technologies and services that build a perception of risk mitigation.

Author Contributions: Formal analysis, S.T.-H. and D.L.; methodology, S.T.-H. and D.L.; supervision, S.T.-H. and D.L.; writing-original draft, S.T.-H. and D.L. All authors have read and agreed to the published version of the manuscript.

Funding: This research received no external funding.

Institutional Review Board Statement: Not applicable.

Informed Consent Statement: Not applicable.

Conflicts of Interest: The authors declare no conflict of interest.

\section{Appendix A. List of Source of Discourses Used to Write the Article}

UNWTO. Available online: https:/ / www.unwto.org/market-intelligence (accessed on 1 June 2021).

UNWTO. Available online: https:/ / www.unwto.org/international-tourism-and-covid-19 (accessed on 1 June 2021).

UNWTO. Available online: https:/ / www.unwto.org/covid-19-travel-restrictions (accessed on 1 June 2021).

UNWTO. Available online: https: / www.unwto.org/more-than-50-of-global-destination s-are-easing-travel-restrictions-but-caution-remains (accessed on 10 September 2020).

UNWTO. Available online: https:/ / www.unwto.org/news/70-of-destinations-have-lifte d-travel-restrictions-but-global-gap-emerging (accessed on 2 December 2020).

BBC News. Available online: https://www.bbc.com/news/world-australia-55048438 (accessed on 23 November 2020).

UNWTO. Available online: https: / / www.unwto.org/news/global-tourism-crisis-committ ee-meets-again-to-explore-safe-travel-in-age-of-vaccines (accessed on 21 January 2021).

UNWTO. Available online: https: / / www.unwto.org/tourism-ethics-a-special-session-oncovid-19-and-tourism (accessed on 1 June 2021).

WHO. Available online: https:/ / www.who.int/news-room/fact-sheets/detail/immuniz ation-coverage (accessed on 1 June 2021).

UNWTO. Available online: https: / / www.unwto.org/news/vaccinate-sids-to-restart-touri sm-kickstart-recovery (accessed on 26 March 2021).

CTV News. Available online: https:/ / www.ctvnews.ca/health/coronavirus/as-the-world -vies-for-vaccines-cuba-s-making-its-own-1.5332446 (accessed on 3 March 2021).

UNWTO. Available online: https:/ / www.unwto.org/unwto-statement-on-the-novel-cor onavirus-outbreak (accessed on 31 January 2020).

UNWTO. Available online: https: / / www.unwto.org/news/unwto-statement-on-the-cont ainment-of-coronavirus-covid-19 (accessed on 28 February 2020). 
UNWTO. Available online: https:/ / www.unwto.org/news/unwto-who-a-joint-statement -on-tourism-and-covid-19 (accessed on 26 February 2020).

UNWTO. Available online: https:/ / www.unwto.org/news/covid-19-statement-zurab-po lolikashvili (accessed on 17 March 2020).

UNWTO. Available online: https:/ /www.unwto.org/news/covid-19-may-statement-un wto-secretary-general (accessed on 15 May 2020).

UNWTO. Available online: https:/ / www.unwto.org/news/as-tourism-restarts-our-respo nsibilities-remain (accessed on 1 July 2020).

UNWTO. Available online: https:/ / www.unwto.org/news/no-time-for-timid-leadershipthe-safe-restart-of-tourism-is-possible (accessed on 18 August 2020).

UNWTO. Available online: https:/ / www.unwto.org/news/global-tourism-plastics-initiat ive-welcomes-26-new-signatories (accessed on 25 November 2020).

UNWTO. Available online: https:/ / www.unwto.org/news/accessible-tourism-identifiedas-game-changer-for-destinations (accessed on 3 December 2020).

UNWTO. Available online: https:/ / www.unwto.org/news/portugal-hosts-unwto-crisis-c ommittee-on-harmonization-of-cross-border-travel-procedures (accessed on 10 December 2020).

UNWTO. Available online: https:/ /www.unwto.org/covid-19-tourisms-restart-brings-h ope-for-millions (accessed on 16 June 2020).

UNWTO. Available online: https:/ / www.unwto.org/news/tourism-back-to-1990-levels-a s-arrivals-fall-by-more-than-70 (accessed on 17 December 2020).

UNWTO. Available online: https:/ /www.unwto.org/news/as-2020-ends-tourism-looksforward-with-determination (accessed on 23 December 2020).

UNWTO. Available online: https://www.unwto.org/news/committee-on-tourism-ethics -recommends-responsible-use-of-travel-certificates (accessed on 14 May 2021).

UNWTO. Available online: https://www.unwto.org/americas/declaration-of-punta-cana -extraordinary-meeting-of-ministers-of-tourism-of-the-americas (accessed on 1 June 2021).

\section{References}

1. World Tourism Organization. UNWTO Tourism Data Dashboard. Available online: https://www.unwto.org/unwto-tourism-da shboard (accessed on 1 June 2021).

2. Wang, M.; Kunasekaran, P.; Rasoolimanesh, S.M. What influences people's willingness to receive the COVID-19 vaccine for international travel? Curr. Issues Tour. 2021, 1-6. [CrossRef]

3. Nalubola, S. Vaccine Passports and COVID-19: Ethical, Scientific, and Practical Considerations. Roundtable J. Health Policy 2021, 3.

4. Adey, P.; Hannam, K.; Sheller, M.; Tyfield, D. Pandemic (Im)mobilities. Mobilities 2021, 16, 1-19. [CrossRef]

5. Goodwin, H. Taking Responsibility for Tourism; Goodfellow Publishers Limited Woodeaton: Oxford, UK, 2011.

6. Young, I.M.; Nussbaum, M. Responsibility for Justice; Oxford University Press (OUP): Oxford, UK, 2013.

7. Weissenrieder, M.; Fairclough, N. Critical Discourse Analysis: The Critical Study of Language. Mod. Lang. J. 1997, 81, 428. [CrossRef]

8. Morgan, M.G.; Jonas, H. The Imperative of Responsibility: In Search of an Ethics in the Technological Age. J. Policy Anal. Manag. 1985, 4, 299. [CrossRef]

9. Levinas, E. Totality and Infinity: An Essay on Exteriority; Springer Science \& Business Media: Berlin, Germany, 1979; Volume 1.

10. Harvey, D. Justice, Nature and the Geography of Difference; Wiley Online Library: Hoboken, NJ, USA, 1996; Volume 468.

11. Dann, G.M. The Language of Tourism: A Sociolinguistic Perspective; Cab International: Wallingford, UK, 1996.

12. Hollinshead, K.; Suleman, R. The Everyday Instillations of Worldmaking: New Vistas of Understanding on the Declarative Reach of Tourism. Tour. Anal. 2018, 23, 201-213. [CrossRef]

13. Hollinshead, K.; Ateljevic, I.; Ali, N. Worldmaking Agency-Worldmaking Authority: The Sovereign Constitutive Role of Tourism. Tour. Geogr. 2009, 11, 427-443. [CrossRef]

14. Minca, C. The Island: Work, Tourism and the Biopolitical. Tour. Stud. 2009, 9, 88-108. [CrossRef]

15. Saarinen, J. Enclavic tourism spaces: Territorialization and bordering in tourism destination development and planning. Tour. Geogr. 2016, 19, 425-437. [CrossRef]

16. Lapointe, D. Reconnecting tourism after COVID-19: The paradox of alterity in tourism areas. Tour. Geogr. 2020, 22, 633-638. [CrossRef]

17. Lapointe, D.; Coulter, M. Place, Labor, and (Im)mobilities: Tourism and Biopolitics. Tour. Cult. Commun. 2020, 20, 95-105. [CrossRef]

18. Ren, C. Non-human agency, radical ontology and tourism realities. Ann. Tour. Res. 2011, 38, 858-881. [CrossRef] 
19. Lapointe, D.; Sarrasin, B.; Benjamin, C. Tourism in the Sustained Hegemonic Neoliberal Order. Rev. Lat. Am. Tur. 2018, 4, 16-33. [CrossRef]

20. Fletcher, R. Sustaining Tourism, Sustaining Capitalism? The Tourism Industry's Role in Global Capitalist Expansion. Tour. Geogr. 2011, 13, 443-461. [CrossRef]

21. Büscher, B.; Fletcher, R. Destructive creation: Capital accumulation and the structural violence of tourism. J. Sustain. Tour. 2016, 25, 651-667. [CrossRef]

22. Guia, J. Conceptualizing justice tourism and the promise of posthumanism. J. Sustain. Tour. 2021, 29, 503-520. [CrossRef]

23. Mura, P.; Wijesinghe, S.N.R. Critical theories in tourism-A systematic literature review. Tour. Geogr. 2021, 10, 1-21. [CrossRef]

24. Foucault, M. L'ordre du Discours; Gallimard: Paris, France, 1972.

25. Wodak, R.; Meyer, M. Methods of Critical Discourse Studies; Sage: Thousand Oaks, CA, USA, 2001.

26. Fletcher, R.; Dressler, W.H.; Anderson, Z.R.; Büscher, B. Natural capital must be defended: Green growth as neoliberal biopolitics. J. Peasant. Stud. 2018, 46, 1068-1095. [CrossRef]

27. Mahrouse, G. Feel-good tourism: An ethical option for socially-conscious Westerners? ACME Int. J. Crit. Geogr. 2011, 10, 372-391.

28. Michaelis, L.; Johnson, G.F. Political Responsibility Refocused: Thinking Justice after Iris Marion Young. In Political Responsibility Refocused, Michaelis, L., Johnson, G.F., Eds.; University of Toronto Press: Toronton, ON, Canada, 2013; pp. 3-20.

29. Jamal, T. Justice and Ethics in Tourism; Routledge: London, UK, 2019.

30. Grimwood, B.S.; Yudina, O.; Muldoon, M.; Qiu, J. Responsibility in tourism: A discursive analysis. Ann. Tour. Res. 2015, 50, 22-38. [CrossRef]

31. Mosedale, J. Political Economy of Tourism; Routledge: London, UK, 2010. [CrossRef]

32. Harvey, D. A Brief History of Neoliberalism; Oxford University Press: New York, NY, USA, 2005.

33. Brown, W. Undoing the Demos: Neoliberalism's Stealth Revolution; Zone Books: New York, NY, USA, 2015.

34. Foucault, M. Naissance de la Biopolitique: Cours au Collège de France (1978-1979); Éditions du Seuil: Paris, France, 2004.

35. Hardnt, M.; Negri, T. Empire; Harvard University Press: Cambrdige, MA, USA, 2000.

36. Mills, C. Biopolitics; Routledge: London, UK, 2017.

37. Rose, J. Biopolitics, Essential Labor, and the Political-Economic Crises of COVID-19. Leis. Sci. 2020, 10, 1-7. [CrossRef]

38. Tremblay-Huet, S. La prédominance, en droit international, des droits des touristes de loisir sur les droits des communautés hôtes. Rev. Gén. Droit 2020, 50, 117-141. [CrossRef]

39. MacCannell, D. The Tourist: A New Theory of the Leisure Class; University of California Press: Berkeley, CA, USA, 1976.

40. Higgins-Desbiolles, F. Socialising tourism for social and ecological justice after COVID-19. Tour. Geogr. 2020, $22,610-623$. [CrossRef]

41. Ateljevic, I. Transforming the (tourism) world for good and (re) generating the potential 'new normal'. Tour. Geogr. 2020, 22, 467-475. [CrossRef]

42. Ek, R.; Tesfahuney, M. The Paradigmatic Tourist. In Tourism Social Science Series; Emerald: Bingley, UK, 2016; Volume 22, pp. 113-129.

43. Hall, C.M.; Scott, D.; Gössling, S. Pandemics, transformations and tourism: Be careful what you wish for. Tour. Geogr. 2020, 22, 577-598. [CrossRef]

44. Marcotte, P.; Khomsi, M.R.; Falardeau, I.; Roult, R.; Lapointe, D. Tourisme et Covid-19. Arrêts sur image et ré-flexions. Téoros. Rev. Rech. Tour. 2020, 39, 3.

45. Brouder, P.; Teoh, S.; Salazar, N.B.; Mostafanezhad, M.; Pung, J.M.; Lapointe, D.; Desbiolles, F.H.; Haywood, M.; Hall, C.M.; Clausen, H.B. Reflections and discussions: Tourism matters in the new normal post COVID-19. Tour. Geogr. 2020, 22, 735-746. [CrossRef]

46. Lapointe, D.; Sarrasin, B.; Lagueux, J. Gestion, biopolitique et prospective: Quels regards pour la suite du monde? Téoros. Rev. Rech. Tour. 2020, 39. Available online: https:/ / www.impactio.com/publication/843885866 (accessed on 7 June 2021).

47. Beck, U. Risikogesellschaft (Risk Society); Suhrkamp: Frankfurt, Germany, 1986. 